\title{
Assessment of CD27 expression on T-cells as a diagnostic and therapeutic tool for patients with smear-negative pulmonary tuberculosis
}

Feifan $\mathrm{Xu}^{1,2}$, Haiyun Zhang ${ }^{2+}$, Xiaoyan $\mathrm{Si}^{2+}$, Junlin $\mathrm{Chen}^{3}$, Yuhao Chen ${ }^{4}$, Xiaopeng Cui ${ }^{4^{*}}$ and Yongwei Qin ${ }^{1 *}$ (D)

\begin{abstract}
Background: There is a global focus on illness diagnosis in smear-negative and latent tuberculosis infectious populations (SN-TB and LTBI). CD27 has been suggested to play a direct role in active TB. Little is known about smear-negative individuals. Here, we tried to investigate whether it has a role in smear-negative populations. The expression of CD27 and MTB-specific CD27 in CD4 ${ }^{+}$T cells ("CD27 ${ }^{-} \mathrm{CD} 4^{+\prime}$ and "CD27 IFN- ${ }^{+} \mathrm{CD} 4^{+\prime}$ ") was evaluated in MTB-unexposed controls (HC), TB contacts (TB-C) and SN-TB individuals by flow cytometry. The sensitivity, specificity and AUC (area under curve) of "CD27-IFN- $\gamma^{+} \mathrm{CD}^{++"}$ cells to distinguish SN-TBs from HCs and TB-Cs were determined by receiver operating characteristic $(\mathrm{ROC})$ curve analysis. The clinical index was selected from the clinical laboratory and evaluated for correlation with "CD27-IFN- $\gamma^{+} \mathrm{CD} 4^{+"}$ cells by Spearman statistical analysis.
\end{abstract}

Results: We observed that the percentages of "CD27-IFN- ${ }^{+} \mathrm{CD}^{+1 "}$ cells were significantly increased in the SN-TB group compared with the HC and TB-C groups (AUC was 0.88 , sensitivity was $82.14 \%$, specificity was $80.00 \%$, and $P<0.0001$ ). The percentage of "CD27 IFN- $\gamma^{+} \mathrm{CD} 4^{+}$" cells was negatively correlated with WBC (white blood cell count) $(r=-0.3019, P=0.0182)$ and positively correlated with IgE (immunoglobulin $E)(r=0.2805, P=0.0362)$.

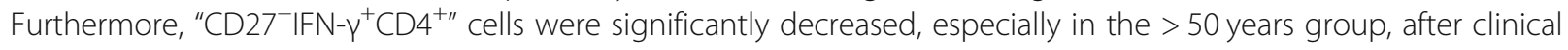
treatment.

Conclusion: The present results demonstrated that the percentage of " $\mathrm{CD} 27^{-} \mathrm{IFN}-\gamma^{+} \mathrm{CD} 4^{+\prime}$ cells might be a conceivable molecular indicator in the diagnosis of SN-TB and was influenced by its outcome of therapy.

Keywords: Smear-negative pulmonary tuberculosis, CD27, Diagnosis, Therapy

\footnotetext{
*Correspondence: cuixiaopeng2000@163.com; yw_qin@foxmail.com

${ }^{\dagger}$ Haiyun Zhang and Xiaoyan Si contributed equally to this work.

${ }^{4}$ Department of General Surgery, Affiliated Hospital of Nantong University, Nantong, China

'Department of Pathogen Biology, School of Medicine, Nantong University, Nantong 226001, China

Full list of author information is available at the end of the article
}

(c) The Author(s). 2021 Open Access This article is licensed under a Creative Commons Attribution 4.0 International License, which permits use, sharing, adaptation, distribution and reproduction in any medium or format, as long as you give appropriate credit to the original author(s) and the source, provide a link to the Creative Commons licence, and indicate if changes were made. The images or other third party material in this article are included in the article's Creative Commons licence, unless indicated otherwise in a credit line to the material. If material is not included in the article's Creative Commons licence and your intended use is not permitted by statutory regulation or exceeds the permitted use, you will need to obtain permission directly from the copyright holder. To view a copy of this licence, visit http://creativecommons.org/licenses/by/4.0/ The Creative Commons Public Domain Dedication waiver (http://creativecommons.org/publicdomain/zero/1.0/) applies to the data made available in this article, unless otherwise stated in a credit line to the data. 


\section{Background}

Mycobacterium tuberculosis (MTB) and its related disease tuberculosis (TB) are infectious diseases with a global focus [1]. Although both vaccines and anti-TB drugs are popular, TB has re-emerged unexpectedly [2]. Globally, almost $20-50 \%$ of TB cases are smear-negative TB (SN-TB) without identifiable bacteriological evidence and are difficult to clinically diagnose [3-5]. According to previous studies, chest X-ray (CXR) and culture were suggested for SN-TB diagnosis, but the pooled sensitivity and specificity were only 61 and 69\%, respectively [6]. Some diagnostic tests, including microscopic observation drug susceptibility assay (MODS) and Xpert analysis, were also performed in the clinic, but all of them have limitations [7]. Recently, immunological assays based on $\mathrm{T}$ cellmediated IFN-gamma responses (i.e., QuantiFERON-TB Gold and T-SPOT. TB) have been proven to be useful in $\mathrm{TB}$ diagnosis with a limitation in distinguishing between latent and active TB $[8,9]$. Hence, a new examination for $\mathrm{SN}-\mathrm{TB}$ is urgently needed.

To a great extent, the cell-mediated immune response is involved in and regulates $\mathrm{MTB}$, and CD4 $\mathrm{T}$ cells are thought to play a momentous role in controlling MTB infection [10]. CD27, a member of the TNF-receptor superfamily, is inextricably expressed on the mature pathogenspecific $\mathrm{CD}_{4}^{+} \mathrm{T}$ cell surface [11]. Previous studies have verified CD27 as an immune biomarker in active TB and pulmonary destruction. Decreased CD27 facilitated differentiated effector $\mathrm{T}$ cell formation and generated many cytokines under inflammatory and/or antigenic stimulation. In infectious diseases, "CD27 $\mathrm{CD} 4^{+"}$ cells accumulated more in peripheral blood and infectious sites, interpreted as a homing process for designated cell subtypes migrating according to infectious organization [12]. Recently, a new strategy based on the CD27 molecular marker was used for active TB diagnosis and could differentiate active TB and latent $\mathrm{TB}$ infection (LTBI) by examining MTBspecific CD27 expression in $\mathrm{CD}^{+} \mathrm{T}$ cells [13]. There is a similar case for detecting the median fluorescence intensity (MFI) ratio for CD27 expression after or without PPD or MTB-specific antigen (ESAT-6/CFP-10) stimuli [14]. These findings provide a possibility for new research on the treatment strategy and underlying mechanism of TB.

In this study, we focused on evaluating several $\mathrm{T}$ cell subcohorts presenting different TB conditions based on smear-negative individuals (aetiology examination negative, T-SPOT positive), especially in special populations such as doctors, nurses and clinical laboratory personnel in TB-specific hospitals. Our studies provided a rapid diagnosis for this population by detecting MTB-specific CD27 expression and secretion of IFN- $\gamma$ in $\mathrm{CD}^{+} \mathrm{T}$ cells. We found that "CD27 ${ }^{-} \mathrm{IFN}-\gamma^{+} \mathrm{CD} 4^{+}$" $\mathrm{T}$ cells accumulated in SN-TB peripheral blood compared with that of $\mathrm{HC}$ individuals and TB-Cs with a correlation with WBC and IgE. Furthermore, we also observed that "CD27 ${ }^{-} \mathrm{IFN}-\gamma^{+} \mathrm{CD} 4{ }^{+}$" cell expression was correlated with the effect of anti-TB treatment.

\section{Results}

Characteristics of the study population

Patient characteristics are shown in Table 1. In the present study, the sex distribution was approximately

Table 1 Characterization of groups included in the study

\begin{tabular}{|c|c|c|c|c|}
\hline Characteristic & $\begin{array}{l}\mathrm{HC} \\
n=34\end{array}$ & $\begin{array}{l}\text { TB-C } \\
n=46\end{array}$ & $\begin{array}{l}\text { SN-TB } \\
n=56\end{array}$ & $P$ value \\
\hline Sex (male/female) & $20 / 14$ & $27 / 19$ & $27 / 29$ & 0.4844 \\
\hline Age (years) & $44.24 \pm 15.15$ & $38.34 \pm 9.42$ & $45.14 \pm 13.52$ & $0.0215^{*}$ \\
\hline $\mathrm{BMI}(\mathrm{kg} / \mathrm{m} 2)$ & $20.89 \pm 2.28$ & $21.54 \pm 2.43$ & $20.26 \pm 2.31$ & $0.0268^{*}$ \\
\hline TSPOT.TB (+) & $0(0 \%)$ & $46(100 \%)$ & $56(100 \%)$ & $<0.0001^{* * *}$ \\
\hline With BCG injected & $33(97.06 \%)$ & $46(100 \%)$ & $52(92.86 \%)$ & 0.1591 \\
\hline WBC $(\times 109 / L)$ & $6.62 \pm 2.08$ & $6.87 \pm 2.15$ & $5.34 \pm 2.12$ & $0.0008^{* *}$ \\
\hline $\mathrm{RBC}(\times 1012 / \mathrm{L})$ & $4.31 \pm 0.60$ & $4.37 \pm 0.52$ & $3.73 \pm 0.84$ & $<0.0001^{* * *}$ \\
\hline $\mathrm{HGB}(\mathrm{g} / \mathrm{L})$ & $128.35 \pm 16.96$ & $129.39 \pm 11.63$ & $121.55 \pm 23.37$ & 0.0738 \\
\hline $\mathrm{PLT}(\times 109 / \mathrm{L})$ & $307.24 \pm 89.91$ & $334.54 \pm 55.67$ & $240.89 \pm 85.52$ & $<0.0001^{* * *}$ \\
\hline $\lg A(g / L)$ & $2.41 \pm 0.98$ & $2.78 \pm 0.98$ & $2.56 \pm 1.43$ & 0.3754 \\
\hline $\lg G(g / L)$ & $11.95 \pm 3.11$ & $10.91 \pm 3.00$ & $10.26 \pm 4.97$ & 0.1508 \\
\hline $\lg M(g / L)$ & $2.33 \pm 0.89$ & $2.12 \pm 1.17$ & $2.16 \pm 1.95$ & 0.8188 \\
\hline $\lg E(I U / m L)$ & $35.53 \pm 88.72$ & $59.42 \pm 165.22$ & $84.05 \pm 176.32$ & 0.3491 \\
\hline $\mathrm{ESR}(\mathrm{mm} / \mathrm{h})$ & $32.35 \pm 47.66$ & $27.50 \pm 42.56$ & $41.75 \pm 35.03$ & 0.2079 \\
\hline CRP (mg/L) & $21.92 \pm 40.34$ & $21.88 \pm 38.90$ & $31.44 \pm 43.61$ & 0.4171 \\
\hline
\end{tabular}

Significant value: ${ }^{*} P<0.05 ;{ }^{* *} P<0.01 ;{ }^{* *} P<0.00001$ 
equal, the SN-TB ( $45.14 \pm 13.52$ years) and $\mathrm{HC}(44.24 \pm$ 15.15 years) groups were older and had a lower BMI $\left(20.26 \pm 2.31 \mathrm{~kg} / \mathrm{m}^{2}, 20.89 \pm 2.28 \mathrm{~kg} / \mathrm{m}^{2}\right)$ than the TB-C $\left(38.34 \pm 9.42\right.$ years, $\left.21.54 \pm 2.43 \mathrm{~kg} / \mathrm{m}^{2}\right)$ group. In the study, SN-TB patients exhibited decreased WBC, RBC and PLT counts $\left(5.34 \pm 2.12 \times 10^{9} / \mathrm{L}, 3.73 \pm 0.84 \times 10^{12} /\right.$ $\left.\mathrm{L}, \quad 240.89 \pm 85.52 \times 10^{9} / \mathrm{L}\right)$ compared to the TB-Cs $\left(6.87 \pm 2.15 \times 10^{9} / \mathrm{L}, \quad 4.37 \pm 0.52 \times 10^{12} / \mathrm{L}, \quad 334.54 \pm\right.$ $\left.55.67 \times 10^{9} / \mathrm{L}\right)$ and $\mathrm{HCs}\left(6.62 \pm 2.08 \times 10^{9} / \mathrm{L}, \quad 4.31 \pm\right.$ $\left.0.60 \times 10^{12} / \mathrm{L}, 307.24 \pm 89.91 \times 10^{9} / \mathrm{L}\right)$. In addition, there was no difference in HGB, IgA, IgG, IgM, IgE, ESR or $\mathrm{CRP}$ among the three groups.

\section{Smear-negative TB patients have higher percentages of "CD27 IFN- $\gamma^{+} \mathrm{CD}^{+"}$ " cells than do MTB-unexposed individuals and TB contacts}

To research the role of $\mathrm{CD} 27$ in SN-TB patients, the percentages of $\mathrm{CD} 27^{-}$cells within the total population of $\mathrm{CD} 4^{+} \mathrm{T}$ cells ("CD27 ${ }^{-} \mathrm{CD} 4^{+}$" cells) were analysed by a flow cytometer. As shown in Fig. 1a-d, compared with $\mathrm{HC}$ and TB-C subjects, SN-TB patients had a high percentage of " $\mathrm{CD} 27^{-} \mathrm{CD} 4^{+}$" $\mathrm{T}$ cells. There was no significant difference between the TB-C and $\mathrm{SN}$ TB patients. To further identify the $\mathrm{CD} 27^{-}$expression of MTB-specific $\mathrm{CD}^{+} \mathrm{T}$ cells, "CD27- IFN $-\gamma^{+} \mathrm{CD} 4^{+}$" cells were evaluated. As shown in Fig. 1e-h, the percentages of "CD27 IFN- $\gamma^{+} \mathrm{CD} 4{ }^{+}$" cells were significantly higher in SN-TB patients but were similar between $\mathrm{HC}$ individuals and TB-C. A ROC curve (Fig. 1i) showed that the expression of "CD27"IFN$\gamma^{+} \mathrm{CD}_{4}^{+}$" could distinguish the SN-TB patients from the $\mathrm{HC}$ and TB-C individuals, and the AUC was 0.88. Moreover, the sensitivity was $82.14 \%$, and the specificity was $80.00 \%$, with a $95 \%$ CI of 0.8214 to 0.9371 (shown in Table 2). In addition, there was also no significant difference between recent and chronic infection in SN-TB patients $(P>0.05$, Fig. 1j). Thus, the expression of $\mathrm{CD}^{2} 7^{-} \mathrm{IFN}-\gamma^{+}$might be a conceivable molecular indicator for detecting $\mathrm{SN}-\mathrm{TB}$ patients.

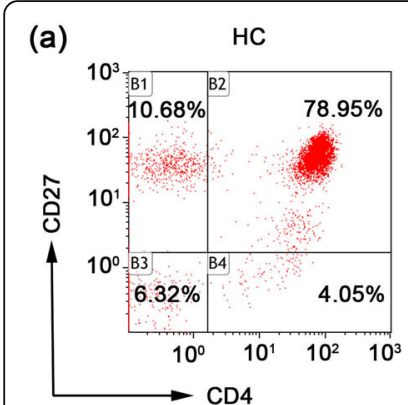

(e)

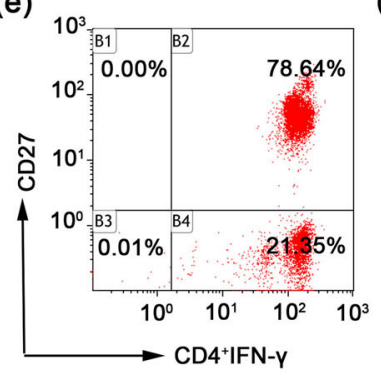

(f)
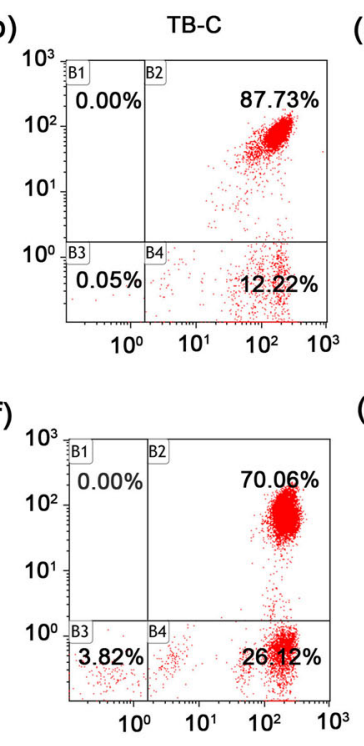

(i)

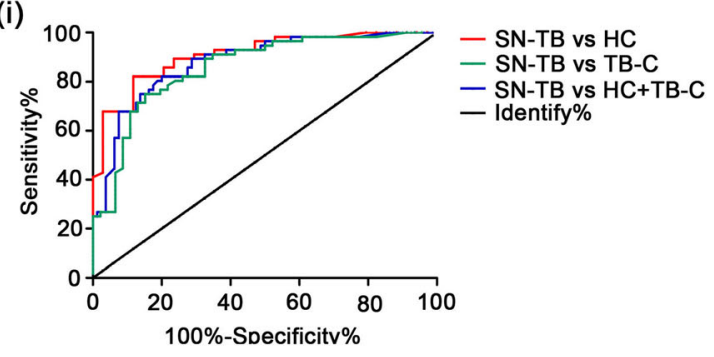

(c)

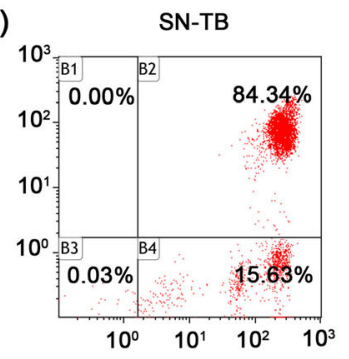

(g)

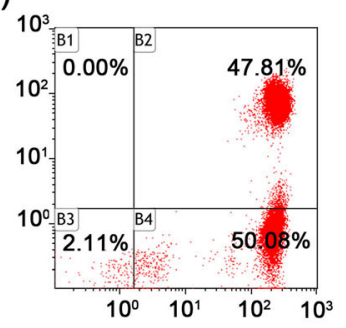

(d)

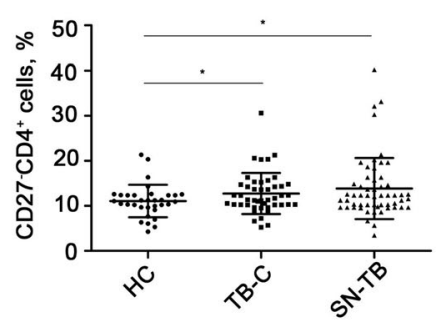

(h)

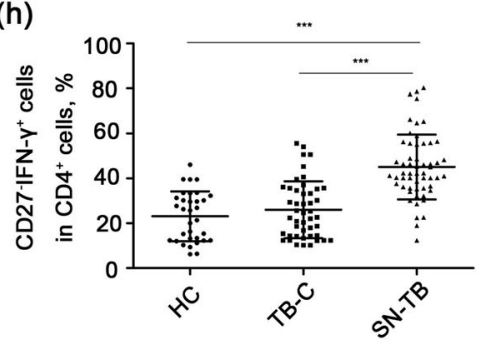

(j)

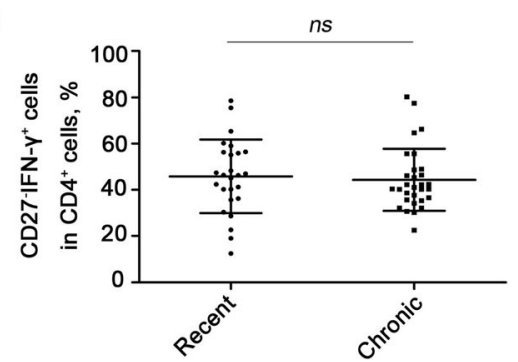

Fig. 1 Smear-negative TB patients have higher percentage of $\mathrm{CD}^{-} 7^{-} \mathrm{IFN}-\gamma^{+}$cells in their peripheral blood. a-d The percentage of CD27 in CD4 T cells population. $\mathbf{e}-\mathbf{h}$ The percentage of "CD27 IFN- $\gamma^{+} \mathrm{CD} 4^{+}$" cells population by a flow cytometry. i ROC-curve of "CD27" IFN- $\gamma^{+} \mathrm{CD} 4^{+"}$ percentages for discriminating SN-TB patients from HC or (and) TB-C. $\mathbf{j}$ The percentage of " $\mathrm{CD} 27^{-} \mathrm{IFN}-\gamma^{+} \mathrm{CD} 4^{+\prime}$ cells population in recent and chronic SN-TB patients. ${ }^{* * *} P<0.0001$ 
Table 2 Distinction smear-negative TB from all health participants by detecting "CD27- $\mathrm{FN}-\gamma^{+} \mathrm{CD} 4^{+ \text {" }}$ cells expression

\begin{tabular}{llllll}
\hline & Sensitivity\% & Specificity\% & AUC & 95\% Cl & P \\
\hline SN TB vs HC and TB C & 82.14 & 88.24 & 0.88 & 0.8214 to 0.9371 & $<0.0001^{* * *}$ \\
SN TB vs HC & 82.14 & 80.00 & 0.91 & 0.8491 to 0.9681 & $<0.0001^{* *}$ \\
SN TB vs TB C & 80.36 & 76.09 & 0.86 & 0.7839 to 0.9312 & $<0.0001^{* *}$ \\
\hline
\end{tabular}

***Significant value $(P<0.0001)$

In smear-negative TB patients, the expression of "CD27 ${ }^{-} \mathrm{IFN}-\mathrm{\gamma}^{+} \mathrm{CD} 4^{+}$" cells in peripheral blood is correlated with WBC counts and IgE expression

To evaluate whether the expression of "CD27-IFN$\gamma^{+} \mathrm{CD}_{4}^{+}$" correlated with the patients' immune state, we analysed "CD $27^{-} \mathrm{IFN}-\gamma^{+} \mathrm{CD} 4^{+}$" expression with clinical laboratory parameters. As shown in Fig. $2 \mathrm{a}$ and $\mathrm{b}$, the percentages of "CD27 ${ }^{-} \mathrm{IFN}-\gamma^{+} \mathrm{CD} 4^{+}$" were negatively correlated with WBC counts $(r=-0.3019, P=0.0182)$ and positively correlated with $\operatorname{IgE}(r=0.2805, P=0.0362)$. There was no significant correlation of "CD27- IFN$\mathrm{\gamma}^{+} \mathrm{CD}^{+}$" cells with the inflammation index (ESR and CRP) or other immunoglobulins (IgG, IgA and IgM) (Supplemental Fig. 2, $P>0.05$ ).

\section{In smear-negative TB patients, the distribution of} "CD27 ${ }^{-} \mathrm{IFN}-\gamma^{+} \mathrm{CD} 4^{+}$" cells in peripheral blood is associated with the effect of the therapy

To evaluate the expression of "CD27 $7^{-} \mathrm{IFN}-\gamma^{+} \mathrm{CD} 4^{+}$" cells in anti-TB therapy, $56 \mathrm{SN}-\mathrm{TB}$ patients enrolled in this study received normal anti-TB therapy. The effect of the treatment was evaluated by clinician and radiologist. In the therapeutic process, blood was collected from all patients into EDTA-anticoagulation tubes. Figure 3a suggests that the percentage of "CD27 ${ }^{-} \mathrm{IFN}-\gamma^{+} \mathrm{CD} 4^{+ \text {" }}$ cells was significantly decreased at 3 and 6 months $(P<0.05$, compared to 0 months). To further investigate the changes in "CD27 $7^{-}$IFN $-\gamma^{+} \mathrm{CD} 4$ " in different age groups, we divided all the patients into three groups $(<30$ with 5 cases, 30-50 with 36 cases and $>50$ groups with 15 cases). As shown in Fig. $3 \mathrm{~b}$, there were no obvious differences in the $<30$ group $(P>0.05$, compared to 0 $M)$ which might be influenced by the limited numbers of cases. Significant differences occurred in the $3 \mathrm{M}$ and $6 \mathrm{M}$ groups at $30-50 \mathrm{M}$ (Fig. 3c, $P<0.05$, compared to $0 \mathrm{M}$ ) and all stages in the $>50$ group (Fig. $3 \mathrm{~d}, P<0.05$, compared to $0 \mathrm{M})$. These results indicated that age might be a key factor in the treatment of SN-TB patients.

\section{Discussion}

In this study, we demonstrated that the percentages of "CD27 ${ }^{-} \mathrm{IFN}-\gamma^{+} \mathrm{CD} 4{ }^{+}$" $\mathrm{T}$ cells rather than "CD27 ${ }^{-} \mathrm{CD} 4^{+}$" cells in SN-TB patients were higher than those of $\mathrm{HC}$ and TB-C individuals. The ROC curve indicated that the AUC was 0.88 (the sensitivity was $82.14 \%$, and the specificity was $80.00 \%$, with a $95 \%$ CI of 0.8214 to 0.9371 ). Moreover, the expression of " $\mathrm{CD} 27^{-} \mathrm{IFN}-\gamma^{+} \mathrm{CD} 44^{+ \text {" corre- }}$ lated with $\mathrm{WBC}$ counts and IgE expression. In addition, we also evaluated the changes in $\mathrm{CD}^{2} 7^{-} \mathrm{IFN}-\gamma^{+}$in the whole $\mathrm{CD}^{+}$T-cell population after normal anti-TB treatment and found that it was significantly decreased in the 30-50-year-old group and > 50-year-old group, particularly at 3 months and 6 months.

Protection against MTB infection is largely dependent on $\mathrm{T}$ cell responses. Although $\gamma \delta \mathrm{T}$ and $\mathrm{CD}^{+}$cells play important roles in protection, $\mathrm{CD}^{+} \mathrm{T}$ cells capable of producing and activating macrophage antimycobacterial functions are thought to be the major immune regulator of MTB [15-17]. Recently, researchers focused their attention on techniques that could more accurately characterize and measure the $\mathrm{CD}^{+} \mathrm{T}$ cell response,
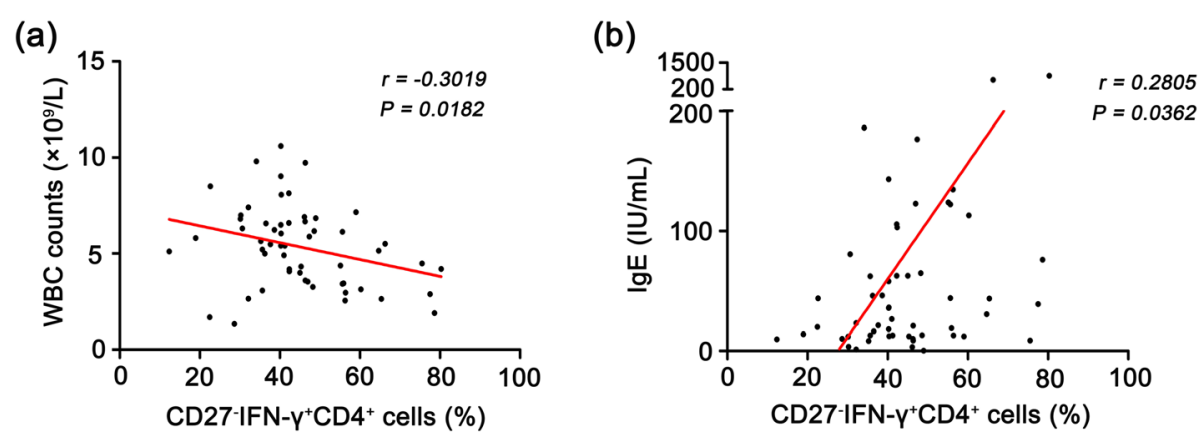

Fig. 2 Relationship between the percentage of "CD27-IFN- $\gamma^{+} \mathrm{CD} 4^{+\prime}$ expression and clinical laboratory index. a Relationship between the percentage of "CD27-IFN- $\gamma^{+} \mathrm{CD} 4^{+\prime}$ expression and WBC counts. $\mathbf{b}$ Relationship between the percentage of "CD27 IFN- $\gamma^{+} \mathrm{CD} 4^{+\prime \prime}$ expression and IgE 

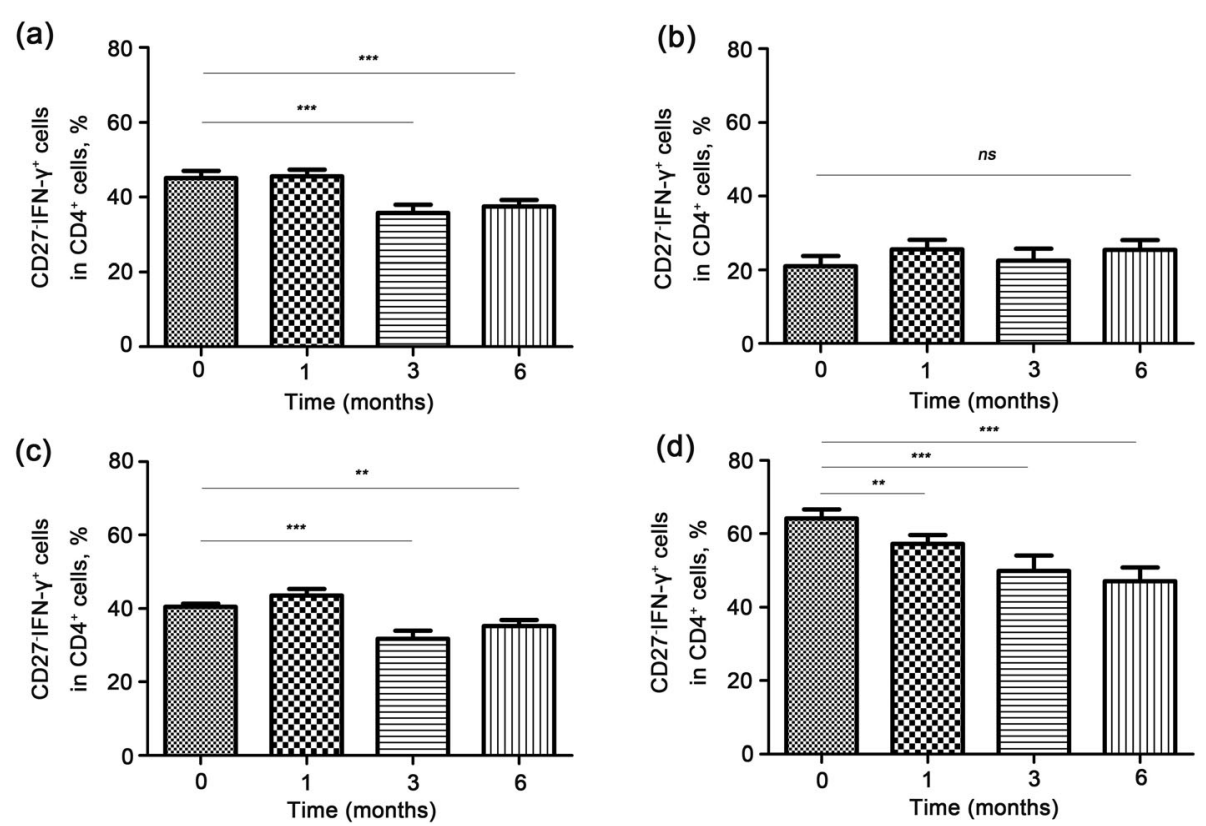

Fig. 3 Distribution and outcome of "CD27- IFN- $\gamma^{+} \mathrm{CD} 4^{+}$" in peripheral blood after normal anti-TB therapy. a Total percentage of " $\mathrm{CD} 27^{-} \mathrm{IFN}-$ $\gamma^{+} \mathrm{CD}^{+}$" cells after treatment. b The percentage of "CD27-IFN- $\gamma^{+} \mathrm{CD} 4^{+\prime \prime}$ in $<30$ years group. $\mathbf{c}$ The percentage of "CD27 IFN- $\gamma^{+} \mathrm{CD} 4^{+\prime}$ in $30-50$ years group. $\mathbf{d}$ The percentage of "CD27-IFN $\gamma^{+} \mathrm{CD}^{+\prime \prime}$ in $>50$ years group. Data are presented as the mean \pm standard deviation of at least three independent experiments. ${ }^{*} P<0.05$ vs. no therapy at 0 month. ${ }^{* *} P<0.01$ vs. no therapy at 0 month. ${ }^{* * *} P<0.0001$ vs. no therapy at 0 month

such as flow cytometry $[18,19]$. In this study, we mainly used flow cytometry to analyse the various molecular characteristics of PBMCs (peripheral blood mononuclear cells). Our data indicating no significant difference in TB contacts and smear-negative TB patients suggested that the expression of $\mathrm{CD} 27$ in $\mathrm{CD}_{4}^{+} \mathrm{T}$ cells could not differentiate healthy, latent $\mathrm{TB}$ infection and smearnegative TB.

Previous studies have verified some cytokine secretion profiles from $\mathrm{CD} 4^{+} \mathrm{T}$ cells in patients with tuberculosis, such as IFN- $\gamma^{+}$, TNF- $\alpha$, IL-2 and CD27 [18, 20, 21]. CD27 is a member of the TNF-receptor superfamily participating in the genesis and development of TB $[19,22$, 23]. Nikitina et al. suggested that $\mathrm{CD}^{2} 7^{-} \mathrm{IFN}-\gamma^{+}$cells play an important role in assessing TB activity, lung destruction, and tissue repair after TB therapy in the majority of smear-positive TB patients [12]. Schuetz et al. indicated that HIV+ patients have higher expression of $\mathrm{CD} 27^{-} \mathrm{IFN}-\gamma^{+} \mathrm{CD} 4^{+} \mathrm{T}$ cells than HIV- persons, suggesting that accumulation of MTB-specific $\mathrm{CD} 27^{-} \mathrm{CD} 4^{+}$cells might reflect the degree of MTB replication, thus affecting subclinical $M$. tuberculosis infection. The loss of $\mathrm{CD} 27$ expression on IFN- $\gamma^{+} \mathrm{CD} 4^{+} \mathrm{T}$ cells in active TB disease in one HIV-infected patient lends further support to this hypothesis [24]. In addition, the TAM-TB assay, which evaluates the ratio of the median fluorescence intensity of CD27 in the whole $\mathrm{CD} 4^{+} \mathrm{T}$-cell population to that of CD27 in the MTB-specific IFN- $\gamma^{+} \mathrm{CD} 4^{+}$ $\mathrm{T}$ cells, has a vital role in distinguishing between tuberculosis in LTBI in adults and children [25]. Nevertheless, studies on SN-TB are rare. Our study focused on 56 smear-negative TB patients and found that $\mathrm{CD} 27^{-} \mathrm{IFN}-\gamma^{+} \mathrm{CD} 4^{+}$was higher in $\mathrm{SN}-\mathrm{TB}$ patients than in MTB-unexposed individuals and TB contacts. The following studies indicated that "CD27 $\mathrm{IFN}-\gamma^{+} \mathrm{CD} 4^{+}$" correlated with the treatment of TB. Examinations based on $\mathrm{T}$ cell responses (TST, T-SPOT, IGRAs) have been widely researched and used in the auxiliary diagnosis of TB [25-27]. Recently, studies have indicated that they have no roles in the discrimination between latent infection and active TB [28]. Our study verified that $\mathrm{CD} 27^{-} \mathrm{IFN}-\gamma^{+}$in the whole $\mathrm{CD} 4^{+}$T-cell population could not distinguish TB-infected patients from healthy controls.

\section{Conclusions}

We demonstrated the increased expression of "CD27-IFN- $\gamma^{+} \mathrm{CD} 4$ " cells in smear-negative TB patients and evaluated its changes after normal anti-TB therapy. These data suggested that "CD27 IFN- $\gamma^{+} \mathrm{CD} 4^{+}$" $\mathrm{T}$ cells could be used to assist the diagnosis of TB and more accurately evaluate the treatment outcome of smearnegative TB.

\section{Methods}

Study subjects and ethics statement

All data were collected in our hospital from July 2016 to August 2018, and the study was approved by the hospital 
ethics committee. All participants enrolled in the study provided written informed consent and did not have any other infectious diseases, such as hepatitis or HIV-1 infection.

\section{Criteria for inclusion and exclusion}

TB was diagnosed based on clinical and radiographic evidence. The HC group included 34 participants with no exposure to MTB and no clinical characteristics of TB, and the PPD test was negative (Table 1). TB-C $(n=46$, Table 1$)$ was the group of doctors and nurses working closely with TB patients for at least 1 year. Of the fifty-six SN-TB patients, all had negative detection of sputum at least 3 times and sputum negative-culture results (Table 1). The patient flow diagram is shown in Supplemental Fig. 1. All fifty-six smear-negative TB patients included in our study had peripheral blood collected and sputum collected at least three times for Ziehl-Neelsen acid-fast stain (Zhuhai DL Biotech Co., Ltd., Guangdong, China). Sputum culture was carried out by BACTEC MGIT 960 (Becton Dickinson, Sparks, USA) liquid culture isolates using the GenoTypeH test system (Hain Lifescience, Nehren, Germany) and improved LJ culture medium (Baso Biotech Co., Ltd., Guangdong, China). The applied SN-TB diagnostic criteria followed the WHO guidelines based on a combination of clinical symptoms, chest radiological evidence, histological observations, other pathogenic detection of sputum and BALF specimens from bronchoscopy and a decision by the attending clinician that the patient had a satisfactory response to all courses of anti-TB therapy [29]. To identify the role of "CD27 ${ }^{-} \mathrm{IFN}-\gamma^{+} \mathrm{CD} 4^{+"} \mathrm{~T}$ cells, peripheral blood was collected from all SN-TB outpatients, and $\mathrm{CD}^{-} 7^{-} \mathrm{IFN}-\gamma^{+}$expression was detected. To compare CD27 expression after TB therapy, all smear-negative patients enrolled in this study received normal anti-TB treatments. Antituberculosis therapy consisted of isoniazid, rifampin, pyrazinamide, and ethambutol daily for 2 months $(\mathrm{M})$ and then isoniazid and rifampin daily for $4 \mathrm{M}$. Peripheral blood was collected at $0 \mathrm{M}, 1 \mathrm{M}, 3 \mathrm{M}$ and $6 \mathrm{M}$. Participants excluded when they were TB aetiology positive, death, combined with other serious infectious disease or lose of follow-up in the research course.

\section{Data extraction}

T-SPOT (tuberculosis infectious T-lymphocyte spot assay, Oxford Immunotec, Abingdon, UK) results were obtained from the clinical laboratory. WBC (white blood cell count), RBC (red blood cell count), HGB (haemoglobin), and PLT (platelet count) assays were carried out using a Mindray BC-6900 hematology analyser (Shenzhen Mindray Bio-Medical Electronics Co., Ltd., China). IgA (immunoglobulin A), IgG (immunoglobulin G), IgM (immunoglobulin M), IgE (immunoglobulin E), and CRP (C-reactive protein) were obtained from Beckman
Coulter 5800 series clinical chemistry analyzer (Tokyo, Japan). ESR (erythrocyte sedimentation rate) were acquired from the Clinical Laboratory Department of our hospital measured by Eriline AR Linear (Barcelona, Spain).

\section{Flow cytometry analysis}

For detection of the whole blood cell surface markers "CD27 ${ }^{-} \mathrm{CD} 4$ " " T cells, $100 \mu \mathrm{l}$ of freshly isolated blood anticoagulated by ethylenediaminetetraacetic acid (EDTA) was stained by FITC-anti-CD27 mAbs and PEanti-CD4 (BD Biosciences, San Jose, USA) at room temperature for $10 \mathrm{~min}$. Red blood cells were lysed by red cell lysis solution (BD Biosciences, San Jose, USA). Cells were collected, washed and analysed by a Beckman Coulter FC500 flow cytometry analysis system (USA). For "CD27 ${ }^{-} \mathrm{IFN}-\gamma^{+} \mathrm{CD} 4^{+}$" cells, $0.5 \mathrm{ml}$ of freshly isolated whole blood was diluted with $0.5 \mathrm{ml}$ of RPMI medium and incubated with the specific MTB mixed antigen (浓 度Biaoyuan Biotech Co. Ltd., Jiangsu, China) at $37^{\circ} \mathrm{C}$ in a $5 \% \mathrm{CO}_{2}$ incubator. Whole blood diluted without antigen stimulation was used as the negative control. After $4 \mathrm{~h}$ of culture, GolgiPlug (BD Biosciences) was added and cocultured overnight. Cells were stained with PEanti-CD4 and FITC-anti-CD27 mAbs for $10 \mathrm{~min}$, and red blood cells were lysed by red cell lysis solution. After centrifugation for $15 \mathrm{~min}$ at $1500 \times \mathrm{g}$, the supernatant was discarded, and cells were treated with BD FACS Lysis solution and BD FACS Permeabilizing solution II, stained with APC-anti- IFN- $\gamma$ mAbs (BD Biosciences, San Jose, USA) for whole blood intracellular staining of IFN- $\gamma$, fixed with $4 \%$ paraformaldehyde and analyzed as above. Lymphocyte were firstly gated by distribution in flow cytometry distinguished from other cell community. For analyzed "CD27 ${ }^{-} \mathrm{CD} 4^{+}$" $\mathrm{T}$ cells, $\mathrm{CD} 4^{+} \mathrm{T}$ cells were gated and analyzed CD27 expression while "IFN$\gamma^{+} \mathrm{CD} 4^{+”}$ cells were gated in detecting $\mathrm{CD} 27$ of "CD27 ${ }^{-} \mathrm{IFN}-\gamma^{+} \mathrm{CD} 4^{+”}$ cells. All flow cytometry results were analyzed by the Kaluza analysis software (USA) supported by Beckman Coulter company.

\section{Statistical analysis}

All data analyses were performed using GraphPad Prism version 5.0 software (San Diego, CA). The difference between unpaired and paired samples was analysed using one-way ANOVA, $t$-test or chi-squared test. For the basic statistics for the patients enrolled in this study, percentiles and the mean \pm SD were used. The sensitivity, specificity, AUC (area under curve) and 95\% CI (95\% confidence interval) were assessed by receiver operating characteristic (ROC) curve analysis. The association between 2 quantitative variables was measured using bivariate correlation (Spearman). A $P$-value of 0.05 was considered significant. 


\section{Abbreviations}

BMI: Body Mass Index; TSPOT.TB: Tuberculosis infectious T-lymphocyte spot assay; WBC: White Blood Cell counts; RBC: Red Blood Cell counts; HGB: Hemoglobin; PLT: Platelet counts; IgA: Immunoglobulin A; IgG: Immunoglobulin G; IgM: Immunoglobulin M; IgE: Immunoglobulin E; ESR: erythorcyte sedimentation rate; CRP: C-reaction protein

\section{Supplementary Information}

The online version contains supplementary material available at https://doi. org/10.1186/s12865-021-00430-y.

Additional file 1: Supplemental Figure 1. The flow diagram. (a) The patient flow diagram. (b) The control flow diagram.

Additional file 2: Supplemental Figure 2. Relationship between the percentage of "CD27 ${ }^{-} \mathrm{IFN}-\gamma^{+} \mathrm{CD} 4^{+\prime}$ expression and other clinical laboratory index. (a) Relationship between the percentage of "CD27-IFN$\mathrm{Y}^{+} \mathrm{CD} 4^{+\prime \prime}$ expression and ESR. (b) Relationship between the percentage of "CD27-IFN- $\gamma^{+} \mathrm{CD}^{+\prime \prime}$ expression and CRP. (c) Relationship between the

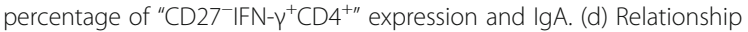
between the percentage of "CD27 IFN- $\gamma^{+} \mathrm{CD} 4^{+"}$ expression and IgG. (e) Relationship between the percentage of " $\mathrm{CD} 27^{-} \mathrm{IFN}-\gamma^{+} \mathrm{CD} 4^{+\prime}$ expression and $\lg \mathrm{M}$.

\section{Acknowledgements}

ot applicable.

\section{Authors' contributions}

YQ designed the study, writing the original draft. FX focused on data curation, formal analysis, and writing-original draft. $\mathrm{HZ}$ and XS helped in all experiments. JC, YC and XC conceived and executed the patients enrolled in the study. All authors had read and approved the final manuscript.

\section{Funding}

The work was supported financially by Nantong Science and Technology Bureau (Grant No. JC2018069), a grant from the Foundation of Nantong sanitation and health committee (Grant No. WKZL2018069) and a project supported by Nantong Junhan business Company (19ZH425). The project was also supported by a grant from China Postdoctoral Science Foundation (2020 M671561), Jiangsu Postdoctoral Science Foundation (2020Z130) and Nantong Science and Technology Program (Grant No.XG202001-4), all these findings providing support for the study design, experiments performance, data collection, analysis, publish and preparation of the manuscript.

\section{Availability of data and materials}

The datasets used and /or analysed during the current study available from the corresponding author on reasonable request.

\section{Declarations}

\section{Ethics approval and consent to participate}

The study protocol was approved by the Medical Ethics Committee of the Sixth People's Hospital of Nantong. Informed written consent was taken from each participant and this procedure was approved by the Medical Ethics Committee.

\section{Consent for publication}

Not applicable.

\section{Competing interests}

The authors report that they have no conflicts of interest or personal relationships that would have appeared to influence the work reported in this paper.

\section{Author details}

'Department of Pathogen Biology, School of Medicine, Nantong University, Nantong 226001, China. ²Department of Clinical Laboratory, The Sixth People's Hospital of Nantong, Nantong 226011, China. ${ }^{3}$ Department of Tuberculosis, The Sixth People's Hospital of Nantong, Nantong 226011,
China. ${ }^{4}$ Department of General Surgery, Affiliated Hospital of Nantong University, Nantong, China.

Received: 24 December 2020 Accepted: 14 June 2021

Published online: 27 June 2021

\section{References}

1. Jung Y, Schluger NW. Advances in the diagnosis and treatment of latent tuberculosis infection. Curr Opin Infect Dis. 2020;33(2):166-72. https://doi. org/10.1097/QCO.0000000000000629.

2. Gautam US, Mehra S, Kumari P, Alvarez X, Niu T, Tyagi JS, et al. Mycobacterium tuberculosis sensor kinase DosS modulates the autophagosome in a DosR-independent manner. Commun Biol. 2019;2(1): 349. https://doi.org/10.1038/s42003-019-0594-0.

3. Yeh J. Validation of a model for predicting smear-positive active pulmonary tuberculosis in patients with initial acid-fast bacilli smear-negative sputum. Eur Radiol. 2018;28(1):243-56. https://doi.org/10.1007/s00330-017-4959-9.

4. Uruga H, Moriguchi S, Takahashi Y, Ogawa K, Murase R, Hanada S, et al. CLINICAL ANALYSIS OF 115 PULMONARY TUBERCULOSIS PATIENTS WITH SPUTUM SMEAR-NEGATIVE. Kekkaku. 2017:92(3):361-4.

5. Lombardi G, Di Gregori V, Girometti N, Tadolini M, Bisognin F, Monte PD. Diagnosis of smear-negative tuberculosis is greatly improved by Xpert MTB/ RIF. PLoS One. 2017;12(4):e176186.

6. Denkinger CM, Kik SV, Cirillo DM, Casenghi M, Shinnick T, Weyer K, et al. Defining the needs for next generation assays for tuberculosis. J Infect Dis. 2015;211(Suppl 2):S29-38. https://doi.org/10.1093/infdis/jiu821.

7. Krishna V, Gopalakrishnan R, Tarigopula A, Panchatcharam SN, Dorairajan SK, Venkatasubramanian R. Utility of Xpert((R)) MTB/RIF in the diagnosis of extrapulmonary tuberculosis. Indian J Med Microbiol. 2019;37(3):448-9. https://doi.org/10.4103/ijmm.IJMM_19_149.

8. Sotgiu G, Saderi L, Petruccioli E, Aliberti S, Piana A, Petrone L, et al. QuantiFERON TB gold plus for the diagnosis of tuberculosis: a systematic review and meta-analysis. J Inf Secur. 2019;79(5):444-53.

9. Boddu D, Verghese VP, Michael JS, Chacko A, Jeyaseelan V. Utility of QuantiFERON((R))-TB gold in-tube test compared with tuberculin skin test in diagnosing tuberculosis in Indian children with malnutrition. Indian J Med Microbiol. 2019;37(3):433-7. https://doi.org/10.4103/ijmm.IJMM_19_227.

10. Toulza F, Tsang L, Ottenhoff TH, Brown M, Dockrell HM. Mycobacterium tuberculosis-specific CD4+ T-cell response is increased, and Treg cells decreased, in anthelmintic-treated patients with latent TB. Eur J Immunol. 2016;46(3):752-61. https://doi.org/10.1002/eji.201545843.

11. Guerra-Maupome M, Palmer MV, Waters WR, McGill JL. Characterization of gammadelta T cell effector/memory subsets based on CD27 and CD45R expression in response to Mycobacterium bovis infection. Immunohorizons. 2019:3(6):208-18. https://doi.org/10.4049/immunohorizons.1900032.

12. Nikitina IY, Kondratuk NA, Kosmiadi GA, Amansahedov RB, Vasilyeva IA, Ganusov W, et al. Mtb-specific CD27low CD4 T cells as markers of lung tissue destruction during pulmonary tuberculosis in humans. PLoS One. 2012;7(8):e43733. https://doi.org/10.1371/journal.pone.0043733.

13. Müller $C$, Rumetshofer $R$, Winkler HM, Bécède $M$, Kneussl M, Winkler $S$. Loss of $T$ cells expressing CD27 at the site of active tuberculosis-a prospective diagnostic study. Tuberculosis (Edinb). 2020;125:102009. https://doi.org/10.1 016/j.tube.2020.102009.

14. Latorre I, Fernández-Sanmartín MA, Muriel-Moreno B, Villar-Hernández R, Vila S. Souza-Galvão ML, et al. Study of CD27 and CCR4 markers on specific CD4+ T-cells as immune tools for active and latent tuberculosis management. Front Immunol. 2019;9:3094. https://doi.org/10.3389/fimmu.2 018.03094 .

15. Florido M, Pillay R, Gillis CM, Xia Y, Turner SJ, Triccas JA, et al. Epitopespecific CD4+, but not CD8+, T-cell responses induced by recombinant influenza a viruses protect against Mycobacterium tuberculosis infection. Eur J Immunol. 2015;45(3):780-93. https://doi.org/10.1002/eji.201444954.

16. Bjerrum S, Broger T, Szekely R, Mitarai S, Opintan JA, Kenu E, et al. Diagnostic accuracy of a novel and rapid Lipoarabinomannan test for diagnosing tuberculosis among people with human immunodeficiency virus. Open Forum Infect Dis. 2020;7(1):Z530.

17. Amelio P, Portevin D, Hella J, Reither K, Kamwela L, Lweno O, et al. HIV Infection Functionally Impairs Mycobacterium tuberculosis-Specific CD4 and CD8 T-Cell Responses. J Virol. 2019;93(5):e01728-18. 
18. Remedios KA, Meyer L, Zirak B, Pauli ML, Truong HA, Boda D, et al. CD27 promotes CD4(+) effector T cell survival in response to tissue self-antigen. J Immunol. 2019;203(3):639-46. https://doi.org/10.4049/jimmunol.1900288.

19. Sun $H$, Zhang $Y$, Song $W$, Yin $L$, Wang $G$, Yu D, et al. IgM(+)CD27(+) B cells possessed regulatory function and represented the main source of $B$ cellderived IL-10 in the synovial fluid of osteoarthritis patients. Hum Immunol. 2019;80(4):263-9. https://doi.org/10.1016/j.humimm.2019.02.007.

20. Adankwah E, Guler A, Mayatepek E, Phillips RO, Nausch N, Jacobsen M. CD27 expression of T-cells discriminates IGRA-negative TB patients from healthy contacts in Ghana. Microbes Infect. 2020;22(1):65-8. https://doi.org/1 0.1016/j.micinf.2019.07.003

21. Saikia L, Deka T, Deori P, Roy R, Hussain ME, Nath R. Frequencies of regulatory subsets of CD4(+) TH cells in peripheral blood in Mycobacterium tuberculosis-infected individuals and healthy contacts in a high-burden setting from Assam, Northeast India. Indian J Med Microbiol. 2019;37(3):3705. https://doi.org/10.4103/ijmm.JJMM_18_439.

22. Latorre I, Fernandez-Sanmartin MA, Muriel-Moreno B, Villar-Hernandez R, Vila S, Souza-Galvao ML, et al. Study of CD27 and CCR4 markers on specific CD4(+) T-cells as immune tools for active and latent tuberculosis management. Front Immunol. 2018;9:3094.

23. von Borstel A, Land J, Abdulahad WH, Rutgers A, Stegeman CA, Diepstra A, et al. CD27(+)CD38(hi) B cell frequency during remission predicts relapsing disease in granulomatosis with Polyangiitis patients. Front Immunol. 2019; 10:2221. https://doi.org/10.3389/fimmu.2019.02221.

24. Schuetz A, Haule A, Reither K, Ngwenyama N, Rachow A, Meyerhans A, et al. Monitoring CD27 expression to evaluate Mycobacterium tuberculosis activity in HIV-1 infected individuals in vivo. PLoS One. 2011;6(11):e27284. https://doi.org/10.1371/journal.pone.0027284.

25. Portevin D, Moukambi F, Clowes P, Bauer A, Chachage M, Ntinginya NE, et al. Assessment of the novel T-cell activation marker-tuberculosis assay for diagnosis of active tuberculosis in children: a prospective proof-of-concept study. Lancet Infect Dis. 2014;14(10):931-8. https://doi.org/10.1016/S1473-3 099(14)70884-9.

26. Anwar MM, Ahmed DM, Elareed HR, Abdel-Latif RA, Sheemy MS, Kamel NM, et al. Screening for latent tuberculosis among healthcare Workers in an Egyptian Hospital Using Tuberculin Skin Test and QuantiFERON-TB gold intube test. Indian J Occup Environ Med. 2019;23(3):106-11. https://doi.org/1 0.4103/ijoem.IJOEM_184_19.

27. Pourakbari B, Mamishi S, Benvari S, Sauzullo I, Bedini A, Valentini P, et al. Can interferon-gamma release assays be useful for monitoring the response to anti-tuberculosis treatment?: a systematic review and meta-analysis. Arch Immunol Ther Exp. 2020;68(1):4. https://doi.org/10.1007/s00005-020-00568-4.

28. Chee CBE, Reves R, Zhang Y, Belknap R. Latent tuberculosis infection: opportunities and challenges. Respirology. 2018;23(10):893-900. https://doi. org/10.1111/resp.13346.

29. WHO global tuberculosis control report 2010. Summary. Cent Eur J Public Health. 2010;18(4):237.

\section{Publisher's Note}

Springer Nature remains neutral with regard to jurisdictional claims in published maps and institutional affiliations.

Ready to submit your research? Choose BMC and benefit from:

- fast, convenient online submission

- thorough peer review by experienced researchers in your field

- rapid publication on acceptance

- support for research data, including large and complex data types

- gold Open Access which fosters wider collaboration and increased citations

- maximum visibility for your research: over $100 \mathrm{M}$ website views per year

At BMC, research is always in progress.

Learn more biomedcentral.com/submissions 